E3S Web of Conferences 1, 10003 (2013)

DOI: $10.1051 / \mathrm{e} 3$ sconf/20130110003

(c) Owned by the authors, published by EDP Sciences, 2013

\title{
Accumulation of Cadmium and Lead in Soils and Vegetables of Lenjanat Region in Isfahan Province, Iran
}

\author{
M. H. Salehi ${ }^{1}$, R. Mohajer ${ }^{2}$ and J. Mohammadi ${ }^{3}$ \\ ${ }^{1}$ Associate Prof., Soil Science Dept., College of Agriculture, Shahrekord University, Shahrekord, Iran, \\ mehsalehi@yahoo.com \\ ${ }^{2}$ Ph.D. Student, Soil Science Dept., College of Agriculture, Shahrekord University, and Scholarship of Payame Noor \\ University, Shahrekord, Iran,r_mohajer2000@yahoo.com \\ ${ }^{3}$ Associate Prof., Soil Science Dept., College of Agriculture, Shahrekord University, Shahrekord, Iran, \\ mohammadi-j@agr.sku.ac.ir
}

\begin{abstract}
Various heavy metals have been reported as dangerous agents to the human health and wildlife when they occur in the environment at high concentrations. Cadmium and lead compounds are classified as human carcinogens by several regulatory agencies. Vegetables grown at environmentally contaminated sites could take up and accumulate metals at concentrations that are probably toxic to human health. In this study, concentrations of cadmium and lead in some of vegetables and soil samples were investigated in different areas of a developed industrial city in Isfahan province, Central Iran. One hundred and thirty topsoil samples and fifty samples of vegetables were collected from agricultural lands and analyzed for heavy metals. The concentration of $\mathrm{Pb}$ and $\mathrm{Cd}$ was more than 5 and $0.5 \mathrm{mg} \mathrm{kg}^{-1}$, respectively. The total of $\mathrm{Cd}$ concentration in most of the soil samples exceeded the suggested Swiss thresholds $\left(0.8 \mathrm{mg} \mathrm{kg}^{-1}\right)$. The results showed that $48 \%$ and $75 \%$ of the vegetables samples had concentrations of $\mathrm{Cd}$ and $\mathrm{Pb}$ exceeded the FAO-WHO limits, respectively. Results from the present study demonstrate that the most of the plants grown on the soils of this region, contaminated with heavy metals, and pose a major health concern.
\end{abstract}

Key words: Heavy metals, Soil contamination, Vegetables, Isfahan

\section{Introduction}

Heavy metals (HMs) such as cadmium and lead present a risk for human health because they are no degradable pollutants, having a large spectrum of effects (e.g., nervous or digestive system disturbances and carcinogenic effects), especially for young children who are more sensitive than adults (Li et al., 2004). Excessive exposure to HMs has been shown to cause various diseases (Jarup, 2003). For most people, the main route of exposure to toxic elements is through dietary intake (Calderon et al., 2003; Roychowdhury et al., 2003). Vegetables constitute an important part of the human diet since they contain carbohydrates, proteins, as well as vitamins, minerals and trace elements (Abdola, and Chmtelnicka, 1990). Metal accumulation in vegetables may pose a direct threat to human health (Damek-Poprawa et al, 2003).

It is believed that vegetables can become contaminated with HMs if they grow on soils contaminated by mining, vehicular exhaust, industrial activities and other agriculture activities (Cui et al., 2004). The levels of HMs in vegetables and soils and their risk to people are of great public concern (Wang et al., 2008, Xie et al., 2006). Vegetables take up metals by absorbing them from contaminated soils, as well as from deposits on different parts of the vegetables exposed to the air from polluted environments (Zurera and Moreno, 1984). Generally Cd accumulation in various plant parts in vegetable crops was increased with the increasing cadmium concentrations in the growth medium. The purpose of this study was to analyze the lead and cadmium concentration of soils and some vegetables grown in Lenjanat region, Isfahan, Iran.

\section{Materials and Methods}

The studied site was located in the Lenjanat region in Isfahan province and the total experiment area of this site was $75 \mathrm{~km}^{2}$. Isfahan is an industrial city in central Iran in 
which intensive agricultural lands surrounded by different industries like steel and cement-making factories and lead mining. The soils of this region are Aridisoils. The average annual rainfall and temperature of the region are $100 \mathrm{~mm}$ and $15.5^{\circ} \mathrm{C}$, respectively.

One hundred and thirty topsoil samples and fifty samples of vegetables from different soil map units were randomly collected and transported to the laboratory.

Basic soil characteristics were determined using common methods. Total concentration of $\mathrm{Cd}$ and $\mathrm{Pb}$ were extracted from the soil samples using concentrated $\mathrm{HNO}_{3}$ (Allen et al., 1986).

Cadmium and lead of plant samples were prepared according to the procedure of Dry-ashing. Heavy metals were extracted by $3 \mathrm{~N} \mathrm{HCl}$. The metal contents of soil and vegetables were determined by flame atomic absorption spectrometry (FAAS).

Descriptive statistics variables including mean, variance, maximum, minimum, coefficient of variation (CV), and skewness were calculated using STATISTICA 6.0 software.

\section{Results and Discussion}

In Table 1, descriptive statistics for heavy metal $(\mathrm{Cd}$ and $\mathrm{Pb}$ ) concentrations in soils and plants was presented. In the soil samples, the concentration of Cd showed a nearly normal distribution whereas concentration of $\mathrm{Pb}$ had a positive skewed distribution. Among parameters, coefficient of variability $(\mathrm{CV})$ is the most discriminating factors for describing variability (Zhang et al., 2007). The $\mathrm{CV}$ of $\mathrm{Cd}$ in this study indicating moderate variability. In comparison, the CVs of plant $\mathrm{Cd}$ and $\mathrm{Pb}$ were $111.76 \%$, and $73.88 \%$, respectively; indicating plant had high variability of $\mathrm{Cd}$ in the study area.

There is no universally accepted safe level for assessing the state of $\mathrm{Cd}$ pollution in soils. Therefore, different levels are used in different countries (Kabata-Pendias and Pendias, 2001). In this study, the environmental standards based on Swiss Federal Office of Environmental, Forest and Landscape were used for the threshold values of heavy metal pollution in the soils (VBBo). In Table 1 , the mean value of $\mathrm{Cd}$ concentration in soils was higher than the threshold of $0.8 \mathrm{mg} \mathrm{kg}^{-1}$ set by VBBo (FOEFL, 1998) and also the maximum allowable limit (1 $\mathrm{mg} \mathrm{kg}^{-1}$ ) set by United Kingdom (Kabata-Pendias and Pendias, 2001), but the mean value of $\mathrm{Pb}$ concentration in soil was less than the threshold of $50 \mathrm{mg} \mathrm{kg}{ }^{-1}$ set by VBBo (FOEFL, 1998). A total concentration of $\mathrm{Cd}$ in $75 \%$ of soil samples is more than $0.8 \mathrm{mg} \mathrm{kg}^{-1}$ and more than $1 \mathrm{mg} \mathrm{kg}^{-1}$ in $67 \%$ of the samples. Abouty $7 \%$ of the data points have more than 2 $\mathrm{mg} \mathrm{kg}^{-1} \mathrm{Cd}$ and more than $1 \%$ have the $\mathrm{Cd}$ concentration higher than $3 \mathrm{mg} \mathrm{kg}^{-1}$. Total soil $\mathrm{Pb}$ content ranged between 1.8 and $115.75 \mathrm{mg} \mathrm{kg}^{-1}$, with a mean value of $14.23 \mathrm{mg} \mathrm{kg}^{-1}$. About $5 \%$ of the samples have $\mathrm{Pb}$ concentration more than the threshold of $50 \mathrm{mg} \mathrm{kg}^{-1}$.

Concentration of $\mathrm{Cd}$ and $\mathrm{Pb}$ elements found in vegetables were also summarized in Table 1. According to the FAO-WHO, the maximum permissible limits of $\mathrm{Cd}$ and $\mathrm{Pb}$ for vegetables and fruits are 0.1 and $0.3 \mathrm{mg} \mathrm{kg}^{-1}$, respectively, on a dry weight basis. The results showed that the levels of $\mathrm{Pb}$ in all vegetable samples were between 0.04 to $8.15 \mathrm{mg} \mathrm{kg}^{-1}$. Cd contents in vegetables varied from no detectable limit by flame atomic absorption spectrometry to $0.9 \mathrm{mg} \mathrm{kg}^{-1}$. In $48 \%$ and $75 \%$ of the vegetables samples, concentrations of $\mathrm{Cd}$ and $\mathrm{Pb}$ exceeded the FAO-WHO limits, respectively. The high contamination found in fruits and vegetables might be closely related to the pollutants in irrigation water, farm soil (Qiu et al., 2000), fertilizers, dusts and also the pollution from the highways traffic. Some of the agrichemicals such as fertilizers contain $\mathrm{Cd}$ and $\mathrm{Pb}$, which are $0.0005-0.5,0.0008-0.93 \mathrm{mg} \mathrm{kg}^{-1}$, respectively (Wang and Ma, 2004). Heavy metal concentrations in our study were lower than the corresponding to metal concentrations detected in the plants grown in contaminated soils of Van region in Eastern Turkey (Turkdogan et al., 2002). Preparing the maps of heavy metals from the soil and dust of the region is recommended for future investigations.

\section{Conclusion}

High heavy metal concentration in the area is associated with a wide range of sources. One of the main sources of $\mathrm{Cd}$ emissions into the environment can be attributed to the active different industries like steel and cement-making factories and $\mathrm{Pb}$ mining in the study area. The accumulation of $\mathrm{Cd}$ and $\mathrm{Pb}$ in fields may also partly be due to the application of agrochemicals. The long-term application of agrichemicals may result in the accumulation of heavy metals in plants so that heavy metal concentrations in some of the vegetables exceeded the threshold values. Results from the present study demonstrate that the most of the plants grown on the soils of this region, contaminated with heavy metals, and pose a major health concern. However, vegetables may be contaminated easily during growing. So, it is important to have a good quality control for these plants in order to protect consumers from contamination. Further investigations on this subject like analyzing of heavy metals content in water and dust of the region could provide us a better insight to know about the pollution of this region and also to solve the problem.

\section{References}

Abdola M, Chmtelnicka J. New Aspects on the Distribution and Metabolism of Essential Trace Elements after Dietary Exposure to Toxic Metals. Biol. Trace Element Res 1990;23:25-53.

Allen SE, Grimshaw HM, Rowland AP. Chemical analysis. In: Moore, P.D., Chapman, S.B. (Eds.), Methods in Plant Ecology. Blackwell Scientific Publication, Oxford, London, 1986 pp. 285-344.

Calderon J, Ortiz-Perez D, Yanez L, Diaz-Barriga F. Human exposure to metals. Pathways of exposure, 
biomarkers of effect, and host factors. Ecotoxicology and Environmental Safetya 2003; 56(1):93-103.

Cui YJ, Zhu YG, Zhai RH, Chen DY, Huang YZ, Qiu Y, Ling JZ. Transfer of metals from soil to vegetables in an area near a smelter in Nanning, China. Environment International 2004;30: 785-791.

Damek-Poprawa M, Sawicka-Kapusta K. Damage to liver, kidney and teats with reference to burden of heavy metals in yellow-necked mice from areas around steelworks and zinc smelters in Poland. Toxicol. 2003;186(1-2):147-158.

FOEFL (Swiss Federal Office of Environment, Forest and Landscape). Commentary on the Ordinance Relating to Pollutants in Soils, VBBo of July 1, 1998, Bern.

Jarup L. Hazards of heavy metal contamination. British Medical Bulletin 2003;68:167-182.

Kabata Pendias A, Pendias H. Trace Elements in Soils and Plants, 3rd ed., CRC Press, USA, 2001. p. 413.

Li X, Lee S.L, Wong S.C, Shi W, Thornton I. The study of metal contamination in urban soils of Hong Kong using a GIS-based approach. Environmental Pollution 2004; 129:113-124.

Qiu XX, Huang DF, Cai SX, Chen F, Ren Z.G, Cai YC. Investigation on vegetables pollution and the pollution sources and its control in Fuzhou, Fujian Province (China). Fujian J. Agric. Sci 2000; 15:16-21.
Roychowdhury T, Tokunaga H, Ando M. Survey of arsenic and other heavy metals in food composites and drinking water and estimation of dietary intake by the villagers from an arsenic-affected area of West Bengal, India. Science of the Total Environment 2003; 308(1-3): 15-35.

Turkdogan MK, Akman N, Tuncer I, Dilek FH. The high prevalence of esophageal and gastric cancers in Eastern Turkey. Med. Biol. Environ 1998; 26: 79-84.

Wang L X, Guo Z H, Xiao X Y, Chen T B, Liao X Y, Song $\mathrm{J}$ et al. Heavy metal pollution of soils and vegetables in the midstream and downstream of the Xiangjiang River, Hunan Province. Journal of Geographical Sciences 2008; 18(3): 353-362.

Wang QC, Ma ZW. Heavy metals in chemical fertilizer and environmental risks, Rural Eco-Environ. 2004; 20 (2): 62-64 (in Chinese).

Xie Z M, Li J, Chen J J, Wu W H. Study on guidelines for health risk to heavy metals in vegetable plantation soils in China. Asian Journal of Ecotoxicolog 2006;1(2):172-179.

Zhang XY, Sui YY, Zhang XD, Meng K, Herbert SJ. Spatial variability of nutrient properties in black soil of northeast China, Pedosphere 2007;17 (1):19-29.

Zurera-Cosano G, Moreno-Rojas R, Salmeron-Egea J, Pozo Lora R. Heavy metal uptake from greenhouse border soils for edible vegetables. J. Sci. Food Agric 1984; 49(3): 307-314.

Table 1. Descriptive statistics of heavy metal concentration in soil and plants of the region.

\begin{tabular}{|c|c|c|c|c|c|c|c|c|}
\hline Flement & Sample & Mean & Minimum & Maximum & Variance & $\mathrm{CV} \%$ & Skewness & Threshold \\
\hline 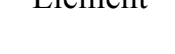 & number & & & & & & & \\
\hline \multicolumn{9}{|l|}{$\mathrm{Cd}$} \\
\hline $\begin{array}{l}\text { in soils } \\
\left(\mathrm{mgkg}^{-1}\right)\end{array}$ & 130 & 1.34 & 0.30 & 3.12 & 0.27 & 38.81 & 0.85 & $0.8^{\mathrm{a}}$ \\
\hline \multicolumn{9}{|l|}{$\mathrm{Pb}$} \\
\hline \multicolumn{9}{|l|}{ in soils } \\
\hline$\left(\mathrm{mgkg}^{-1}\right)$ & 130 & 14.23 & 1.8 & 115.75 & 226.33 & 110.75 & 4.76 & $50^{a}$ \\
\hline \multicolumn{9}{|l|}{$\mathrm{Pb}$} \\
\hline $\begin{array}{c}\text { in vegetable } \\
\left(\mathrm{mgkg}^{-1}\right)\end{array}$ & 50 & 2.91 & 0.04 & 8.15 & 4.65 & 73.88 & 0.34 & $0.3^{b}$ \\
\hline \multicolumn{9}{|l|}{$\mathrm{Cd}$} \\
\hline $\begin{array}{c}\text { in vegetable } \\
\left(\mathrm{mgkg}^{-1}\right)\end{array}$ & 50 & 0.17 & N.D ${ }^{c}$ & 0.9 & 0.036 & 111.76 & 1.95 & $0.1^{b}$ \\
\hline
\end{tabular}

